\title{
Variable temperature sample cell and optical mount for laser Raman studies of adsorbed species
}

\author{
G. L. Schrader, Jr. and C. G. Hill, Jr. \\ Department of Chemical Engineering, University of Wisconsin, Madison, Wisconsin 53706 \\ (Received 4 April 1975; in final form, 16 June 1975)
}

\begin{abstract}
A sample cell and optical mount for use in laser Raman spectroscopic studies of adsorbed species at elevated temperatures is described. In situ Raman spectra of pyridine adsorbed on $60-120$ mesh silica gel at room temperature, $75^{\circ} \mathrm{C}$, and $150^{\circ} \mathrm{C}$ are reported. The cell has also been used in studies of other species adsorbed on silica, alumina, and platinum wire.
\end{abstract}

\section{INTRODUCTION}

In recent years a few groups have recorded the laser Raman spectra of various adsorbed species. ${ }^{1-7}$ Such studies provide information about the nature of the adsorbate-adsorbent interaction and are of particular interest to workers in the field of heterogeneous catalysis because of the different effects which arise in chemical and physical adsorption. The studies reported to date have involved recording the room temperature spectra of different chemical species in relatively simple sample holding devices. From the standpoint of the research worker in heterogeneous catalysis, one would like to be able to record the laser Raman spectra under in situ reaction conditions with a reasonable variable temperature capability. The various apparatus described by previous investigators are not suitable for such studies.

This note describes a combination batch reactor-sample holder and a sample positioning apparatus which have been used in studies of species sorbed on powdered samples. It would appear to be a relatively simple task to modify the cell to permit its use as a continuous flow reactor with operation in either a recycle or single pass mode. This work is currently in progress.

\section{VARIABLE TEMPERATURE RAMAN CELL}

The Raman cell for surface studies is shown in Fig. 1. The Pyrex cell is an extension of a Kovar-to-Pyrex seal. The adsorbent is placed in the central tube for bakeout and evacuation and for recording spectra. The outer tube

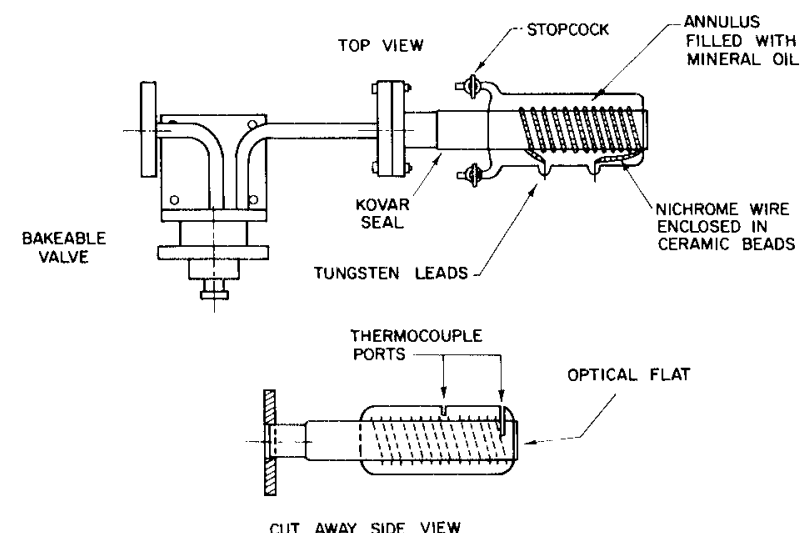

FIG. 1. Raman cell for surface studies. encloses the heating element and heat conduction fluid which are used for elevated temperature spectra. The heating circuit consists of Nichrome wire enclosed in ceramic beads; connection to an external power supply is made through tungsten leads. Mineral oil is used as the heat conduction fluid and is introduced into the annulus through the stopcocks. Laser excitation occurs via an optical flat which is sealed to the end of the tubes.

The Kovar-to-Pyrex seal is silver soldered to a stainless steel flange and is attached to an all metal bakeable valve (Granville-Phillips type $C$ ultrahigh vacuum valve). This valve can then be connected to a conventional vacuum system for bakeout and evacuation. The gaskets used in all connections are silver plated OFHC copper. A porous stainless steel disk inserted in the inlet port of the bakeable valve prevents the adsorbent from being pulled into the vacuum system during sample preparation. The entire system can be baked out under vacuum or under a specific atmosphere at temperatures up to $450^{\circ} \mathrm{C}$.

This assembly has the following advantages:

(1) The entire assembly, rather than only a portion of the cell, can be baked out under high temperatures.

(2) The use of an all-metal valve and the associated gaskets eliminates the presence of vacuum grease in the proximity of the cell. One of the difficulties of using Raman spectroscopy to study surfaces is the presence of fluorescence which appears as a broad band with a half-width of about

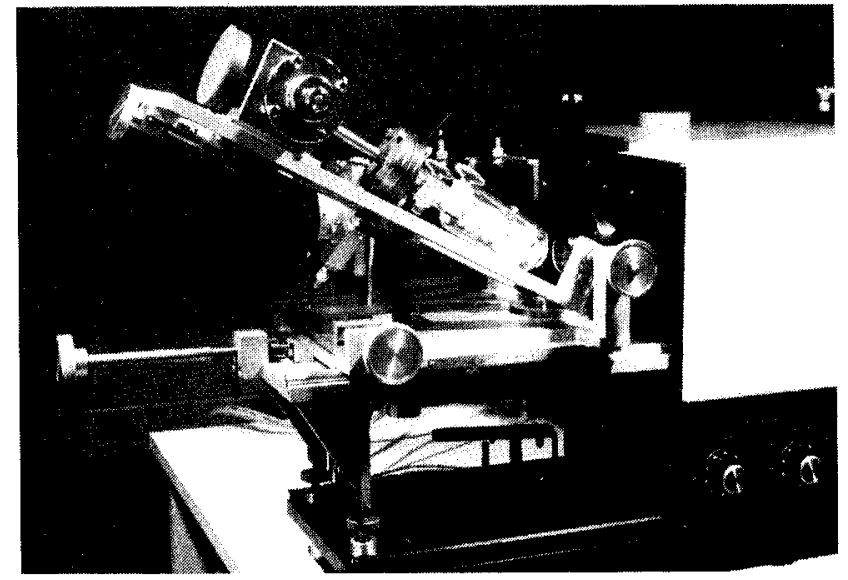

FIG. 2. Optical arrangement for data collection. 
$2000 \mathrm{~cm}^{-1}$. This fluorescence is generally felt to be the result of strongly adsorbed traces of hydrocarbon impurities.

\section{EXCITATION AND COLLECTION OPTICS}

The laser Raman spectrometer employed in these studies utilized a Spex Industries model 1401 double monochromator and "third monochromator." Slit settings on the double monochromator were $250 \mu$, which gave a resolution of about $5 \mathrm{~cm}^{-1}$ at $20492 \mathrm{~cm}^{-1}$. The position of the sample cell and optical mount relative to the excitation and collection optics is shown in Fig. 2. An interference filter for the $20492 \mathrm{~cm}^{-1}$ line of an argon laser was used for most spectra. A 16-mm microscope lens directs the laser beam onto the sample. The laser beam was defocused at the surface to increase the sample area exposed to the beam and to minimize local heating effects. An optical mount designed for use in a Spex Ramalog system is used to position the cell in the laser beam. The mounts allows for five degrees of freedom in positioning the sample: translation parallel to the laser beam, translation parallel to the spectrophotometer axis, translation perpendicular to the plane containing the spectrophotometer axis and the laser beam, rotation about an axis of the laser beam, and rotation about an axis perpendicular to the beam. Two degrees of freedom in positioning the laser beam are also available from the spectrophotometer optics. Scattered radiation is collected at $90^{\circ}$ by an $j / 1$ lens system. This system consists of a photographic closeup lens, an Astro-Berlin lens with a $35-\mathrm{mm}$ effective focal length, and a telescope lens which is mounted on the Astro-Berlin lens.

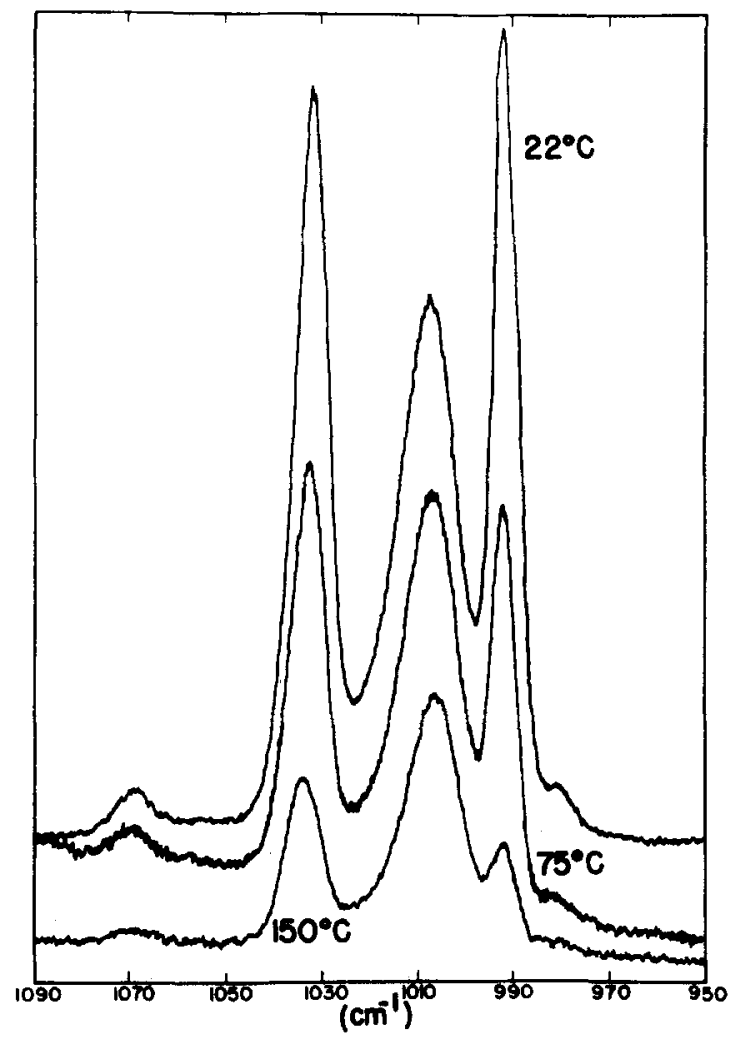

Fig. 3. Pyridine adsorbed on silica gel as a function of temperature $\left({ }^{\circ} \mathrm{C}\right) . P=1.86 \times 10^{-2}$ bar.
TABLE I. Spectra of pyridine adsorbed on silica gel $\left(\Delta \nu\right.$ in $\left.\mathrm{cm}^{-1}\right)$. Abbreviations: $h$-high coverage $\left(1.86 \times 10^{-2}\right.$ bar $) ; 1$ low coverage $\left(10^{-6}\right.$ bar $)$; br-broad.

\begin{tabular}{|c|c|c|c|c|}
\hline Liquid & $\begin{array}{l}\text { Schrader } \\
\text { and Hill }\end{array}$ & $\begin{array}{l}\text { Relative } \\
\text { intensity }\end{array}$ & $\begin{array}{l}\text { Egerton et al. } \\
\quad(1974)\end{array}$ & $\begin{array}{l}\text { Kage }^{3} \\
(1970)\end{array}$ \\
\hline 408 & $409(\mathrm{~h})$ & 2 & & \\
\hline 604 & $604(h)$ & 4 & $605(\mathrm{~h})$ & 604 \\
\hline (absent) & $\begin{array}{l}619(\mathrm{~h}) \\
620(1)\end{array}$ & 4 & $617(\mathrm{~h})$ & \\
\hline 653 & $\begin{array}{l}652(\mathrm{~h}) \\
654(\mathrm{l})\end{array}$ & 19 & $655(\mathrm{~h})$ & 655 \\
\hline 711 & $706(\mathrm{br})$ & 1 & & \\
\hline 886 & $\begin{array}{l}887(h) \\
886(l)\end{array}$ & 2 & & \\
\hline 942 & $946(h)$ & 2 & & \\
\hline 981 & $981(\mathrm{~h})$ & 6 & & \\
\hline 992 & $991(\mathrm{~h})$ & 81 & $991(\mathrm{~h})$ & 992 \\
\hline (absent) & $\begin{array}{l}1007(\mathrm{~h}) \\
1006(\mathrm{l})\end{array}$ & 54 & $\begin{array}{l}1008(h) \\
1006(l)\end{array}$ & \\
\hline 1031 & $\begin{array}{l}1032(\mathrm{~h}) \\
1036(\mathrm{l})\end{array}$ & 74 & $\begin{array}{l}1032(h) \\
1035(1)\end{array}$ & 1032 \\
\hline 1069 & $\begin{array}{l}1069(h) \\
1070(\text { I) }\end{array}$ & 5 & & \\
\hline 1148 & $\begin{array}{l}1151(\mathrm{~h}) \\
1153(\mathrm{l})\end{array}$ & 3 & & \\
\hline 1218 & $\begin{array}{l}1218(\mathrm{~h}) \\
1221(\mathrm{l})\end{array}$ & & $1219(\mathrm{~h})$ & 1220 \\
\hline 1483 & $\begin{array}{l}1485(h) \\
1489(1)\end{array}$ & 3 & & \\
\hline 1575 & $\begin{array}{l}1577(\mathrm{~h}) \\
1579(\mathrm{l})\end{array}$ & 15 & $1578(\mathrm{~h})$ & \\
\hline 1582 & $\begin{array}{l}1597(\mathrm{~h}) \\
1599(\mathrm{l})\end{array}$ & 12 & $1600(\mathrm{~h})$ & \\
\hline 2920 & $\begin{array}{l}2923(\mathrm{~h}) \\
2926(\mathrm{l})\end{array}$ & 3 & & \\
\hline 2956 & $\begin{array}{l}2958 \text { (h) } \\
2964(\mathrm{~h}) \\
2967 \text { (l) }\end{array}$ & $\begin{array}{l}5 \\
5\end{array}$ & & \\
\hline 2990 & $\begin{array}{l}2992(\mathrm{~h}) \\
3001 \text { (h) } \\
3006(\mathrm{l})\end{array}$ & $\begin{array}{l}5 \\
5\end{array}$ & & \\
\hline${ }^{3057}$ shoulder & $\begin{array}{r}3059(\mathrm{~h}) \\
3070(\mathrm{~h}) \\
3073(\mathrm{l})\end{array}$ & 63 & $\begin{array}{l}3061 \text { (h) } \\
3070 \text { (l) }\end{array}$ & 3061 \\
\hline \multicolumn{5}{|l|}{3090} \\
\hline 3148 & $\begin{array}{l}3149(\mathrm{~h}) \\
3155(\mathrm{l})\end{array}$ & 4 & & \\
\hline
\end{tabular}

\section{OPERATING TECHNIQUES}

Sample preparation prior to contact with adsorbate begins by insertion into the cell and evacuating to $10^{-5}$ bar or lower for about an hour. An oxygen atmosphere of about $0.6 \mathrm{bar}$ is then introduced, and the temperature of the entire assembly is raised to the desired temperature, typically $300^{\circ}-400^{\circ} \mathrm{C}$. Several purges of the oxygen atmosphere are performed during the $12-15 \mathrm{~h}$ of sample preparation. The sample is then evacuated at the desired bakeout temperature. Ultimate pressures are in the $10^{-8}-10^{-9}$ bar region.

When the evacuation has been completed, the temperature is reduced, and the annulus filled with the heat conduction fluid. The temperature at which the spectrum is to be recorded is maintained by the heating element, and the adsorbate is introduced. The cell is then detached from the 
vacuum system and attached to the optical mount. An incident beam angle of $70^{\circ}$ was found to give the highest signal-to-noise ratio. A black cloth was used to cover the assembly to reduce stray radiation.

\section{LASER RAMAN SPECTRUM OF PYRIDINE ON SILICA GEL}

Our studies of pyridine on silica gel are consistent with those reported in the literature but differ from them in two significant respects. First we have been able to observe many more lines arising from adsorbed species than have been reported previously. Our sensitivity represents a significant improvement over those obtained by previous investigators. Second, all previous spectra have been recorded with the sample maintained at room temperature, whereas some of our spectra have been obtained at elevated temperatures.

Figure 3 is a variable temperature scan of the 950-1090 $\mathrm{cm}^{-1}$ region of pyridine adsorbed on silica gel $(\mathrm{BDH}$ chromatographic grade, $60-120 \mathrm{mesh}, 650 \mathrm{~m}^{2} / \mathrm{g}$ ). Silica gel at the indicated temperatures was exposed to pyridine vapor for $40 \mathrm{~min}$. The spectrum was then recorded while maintaining the indicated temperatures. A moderate increase in fluorescence was observed at higher temperatures.

Table I clearly indicates that significant improvements in sensitivity and signal-to-noise ratio were achieved. Many low intensity peaks not previously observed were recorded because of several improvements in instrumentation and experimental technique. Heating the silica gel under an oxygen atmosphere for several hours greatly reduces the fluorescence, as reported by previous workers. ${ }^{6}$ In addition, the use of an all-metal valve in the sample cell eliminated the presence of vacuum grease near the sample. Our results support the hypothesis that the fluorescence is due to traces of hydrocarbon impurities. Several other aspects of the instrumentation have also been useful in increasing the signal-to-noise ratio. Use of the optical mount was essential for observing low intensity lines. The sample cell had to be accurately positioned for efficient excitation of the sample by the laser and for optimal collection of the scattered radiation. The use of a closeup lens substantially increased the amount of scattered radiation directed into the slits of the monochromator. Removal of the Claassen filter and the use of an interference filter for the $20492 \mathrm{~cm}^{-1}$ line also led to an improvement in the signal-to-noise ratio because of the increased power incident on the sample. In general, no changes were observed in the spectrum of pyridine adsorbed on silica gel for laser powers as high as $800 \mathrm{~mW}$.

The results obtained with this equipment thus far indicate its potential utility for the study of adsorbed species, especially at elevated temperatures. A more detailed description of the results for the pyridine/silica gel system is being prepared for publication at a later date. ${ }^{8}$

\section{ACKNOWLEDGMENT}

G. L. Schrader was supported as a National Science Foundation Fellow during the course of this work. Technical assistance by David M. Coleman and Professor Paul Bender is gratefully acknowledged. Thomas Lloyd assisted in the design and fabrication of the optical mount. The Chemistry Department was generous in making time available on the spectrometer purchased under NSF Grant $144 \mathrm{C} 693$.

${ }^{1}$ P. J. Hendra and E. J. Loader, Trans. Faraday Soc. 67, 828 (1971). 2P. J. Hendra, J. R. Horder, and E. J. Loader, J. Chem. Soc. A $1766(1971)$.

${ }^{3}$ R. O. Kagel, J. Phys. Chem. 74, 4518 (1970)

${ }^{4} \mathrm{E}$. Buechler and J. Turkevich, J. Phys. Chem. 76, 2325 (1972). ${ }^{5}$ C. L. Angell, J. Phys. Chem. 77, 222 (1973).

${ }^{6}$ T. A. Egerton, A. H. Hardin, Y. Kozirovski, and N. Sheppard, J. Catal. 32, 343 (1974).

${ }^{7}$ P. J. Hendra, I. D. M. Turner, E. J. Loader, and M. Stacey, J. Phys. Chem. 78, 300 (1974).

${ }^{8}$ G. L. Schrader, Jr. and C. G. Hill, Jr., J. Catal. (to be published). 